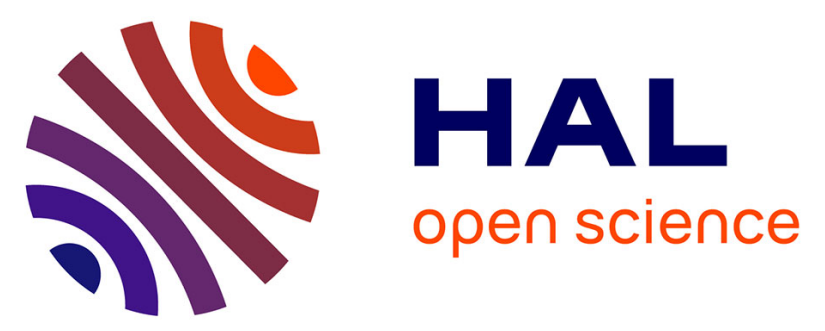

\title{
Cervical Infection with Human Papillomavirus (HPV) 6 or 11 in High-Risk Women in Burkina Faso
}

\author{
Andrea Low, Marie-Noelle Didelot-Rousseau, Nicolas Nagot, Abdoulaye \\ Ouedraougo, Tim Clayton, Issouf Konate, Philippe van de Perre, Michel \\ Segondy, Philippe Mayaud
}

\section{To cite this version:}

Andrea Low, Marie-Noelle Didelot-Rousseau, Nicolas Nagot, Abdoulaye Ouedraougo, Tim Clayton, et al.. Cervical Infection with Human Papillomavirus (HPV) 6 or 11 in High-Risk Women in Burkina Faso. Sexually Transmitted Infections, 2010, 86 (5), pp.342. 10.1136/sti.2009.041053 . hal-00557465

\section{HAL Id: hal-00557465 \\ https://hal.science/hal-00557465}

Submitted on 19 Jan 2011

HAL is a multi-disciplinary open access archive for the deposit and dissemination of scientific research documents, whether they are published or not. The documents may come from teaching and research institutions in France or abroad, or from public or private research centers.
L'archive ouverte pluridisciplinaire $\mathbf{H A L}$, est destinée au dépôt et à la diffusion de documents scientifiques de niveau recherche, publiés ou non, émanant des établissements d'enseignement et de recherche français ou étrangers, des laboratoires publics ou privés. 


\section{Cervical Infection with Human Papillomavirus (HPV) 6 or 11 in High-Risk Women in Burkina Faso}

Andrea Low ${ }^{1}$, Marie-Noelle Didelot-Rousseau ${ }^{2}$, Nicolas Nagot $^{1,2,3}$, Abdoulaye Ouedraougo $^{3}$, Tim Clayton ${ }^{1}$, Issouf Konate ${ }^{2}$, Philippe Van de Perre ${ }^{2}$, Michel Segondy ${ }^{2}$, and Philippe Mayaud $^{1}$

${ }^{1}$ London School of Hygiene \& Tropical Medicine, London, UK

${ }^{2}$ CHU Montpellier, Laboratoire de Bactériologie-Virologie and Département d’Information Médicale, Montpellier, France

${ }^{3}$ Centre Muraz, Bobo-Dioulasso, Burkina Faso

Author for correspondence: Philippe Mayaud, Clinical Research Unit, Department of Infectious \& Tropical Diseases, London School of Hygiene \& Tropical Medicine, London WC1E 7HT, UK.

Tel: +44 (0)207927 2291;

Fax: +44 (0)207 6374314 :

email: philippe.mayaud@1shtm.ac.uk

Key words: Low-risk Human Papillomavirus (LR-HPV); HIV-1; genital warts; genital ulcer disease; Africa. 


\begin{abstract}
Objectives: Human papillomavirus (HPV) types 6 and 11 are known agents of genital warts but little is known about their epidemiology in Africa. We present data on the prevalence of, and risk factors for, cervical HPV 6 and 11 in high-risk women in Burkina Faso.
\end{abstract}

Methods: 306 women were enrolled. HIV status and CD4+ counts were determined. Among other genital samples, a cervical swab (Cervex) was collected for liquid-based cytology and HPV genotyping using MY09/MY11 and GP5+/GP6+ PCRs, and INNO-LiPA genotyping v2. Risk factors were examined using logistic regression.

Results: HIV-1 seroprevalence was 40\% (123/306). Cervical HPV DNA was detected in $55 \%(100 / 183)$ of HIV-uninfected women, 84\% (78/93) of HIV-1 infected women with CD4+ T-cell counts $>200$ cells/ $\mu 1$ and 97\% (29/30) of HIV-1 infected women with CD4+ Tcell counts $\leq 200$ cells/ $\mu$ l ( ptrend $\left._{\text {tro. }}<001\right)$. HPV 6 prevalence was $6 \%(18 / 306)$, HPV 11 prevalence 4\% (13/306), and overall HPV 6/11 prevalence 9\% (28/306), which increased with HIV infection and immuno-suppression. Genital warts were associated with HPV 6 (adjusted OR=4.12, 95\% CI: 1.17-14.53) but not with HPV 11. Genital ulcerations were associated with HPV 6/11 but not with other HPV types. There was a protective effect for vaginal douching and the follicular phase of the menstrual cycle. Condom use, HIV-1 plasma viral load, and other STI/RTIs were not associated with HPV 6/11.

Conclusions: Prevalence of HPV 6/11 was high in this population, with predominance of HPV 6. HPV 6/11 were found more frequently in women with genital ulcers and in those with HIV-related immunosuppression. 


\section{Introduction}

Human papillomaviruses (HPV) are the most common sexually transmitted infections worldwide.[1] The low oncogenic risk types HPV (LR-HPV) 6 and 11 are the major causative agents of genital warts.[2] The epidemiology of these HPV types is poorly described in Africa. As HPV vaccines become more widely available, it becomes important to understand the epidemiology of vaccine-associated HPV types. We present data on the prevalence of, and risk factors for, cervical HPV 6 and 11 in high-risk women in Burkina Faso.

\section{Methods}

Data were obtained from a cross-sectional survey of high-risk women nested within the Yerelon Cohort study, which has been evaluating interventions to reduce the risk of HIV infection among sex workers in Bobo-Dioulasso since 1998.[3]

Between December 2003 and March 2004, cohort participants were asked for permission to collect a cervical swab (Cervex) for liquid-based cytology and HPV-DNA detection using MY09/MY11 and GP5+/GP6+ PCRs and genotyping with INNO-LiPA genotyping v2 (Innogenetics).[4,5] Vaginal and cervical swabs were collected for the diagnosis of Trichomonas vaginalis and bacterial vaginosis (BV) by microscopy, and Candida albicans and Neisseria gonorrhoeae by culture. Blood samples were collected for HIV, syphilis, and HSV-2 serologies, and HIV-1 plasma viral load and CD4+ count in HIV-1 seropositive women. Statistical analysis was conducted using logistic regression. Ethical approval was obtained from the Ethics Committees of the Burkina Faso Ministry of Health and the London School of Hygiene \& Tropical Medicine. 


\section{Results}

Of 379 cohort participants enrolled during the study period, 306 had data on HPV and concurrent clinical and laboratory information. The median age was 26 years (range 15-54 years), median age at first intercourse was 17 years (range 10-24), and 64 women (21\%) described themselves as full-time sex workers. HIV-1 seroprevalence was 40\% (123/306), syphilis seroprevalence was 3\% (9/303) and HSV-2 seroprevalence was 68\% (195/285).

Cervical HPV DNA was detected in 55\% (100/183) of HIV-uninfected women, 84\% (78/93) of HIV-1 infected women with CD4+ counts > 200 cells/ $\mu 1$ and 97\% (29/30) of HIV-1 infected women with CD4+ counts $\leq 200$ cells $/ \mu 1$ ( $\left.p_{\text {trend }}<0.001\right)$. HPV 6 prevalence was $6 \%$ (18/306), HPV 11 prevalence 4\% (13/306), and overall HPV 6/11 prevalence 9\% (28/306), which increased with HIV infection and immunosuppression (Table 1).

Among the 18 women with genital warts, 4 were positive for HPV 6 (adjusted OR=4.12, 95\% CI: 1.17-14.53, $\mathrm{p}=0.03$ ) but none were positive for HPV 11. Genital ulcerations were positively associated with cervical HPV 6/11 but not with other HPV types. Regular vaginal douching and the follicular phase of the menstrual cycle were associated with lower HPV 6/11 prevalence. Condom use, HIV-1 plasma viral load, and other STI/RTIs were not associated with HPV 6/11. 
Table 1. Multivariate associations with cervical HPV 6/11 and other HPV types in 306 high-risk women in Burkina Faso

\begin{tabular}{|c|c|c|c|c|c|c|}
\hline Characteristic & $\mathbf{N}$ & $\begin{array}{c}\text { Women with } \\
\text { HPV 6/11 } \\
\text { n }(\%)\end{array}$ & $\begin{array}{c}\text { HPV } 6 \text { or } 11 \\
\text { adjusted OR } \\
(95 \% \mathrm{CI})^{\mathrm{a}}\end{array}$ & P-value & $\begin{array}{c}\text { Other HPV types } \\
\text { adjusted OR } \\
(95 \% \mathrm{CI})^{\mathrm{a}}\end{array}$ & P-value \\
\hline \multicolumn{7}{|l|}{ Age groups, years } \\
\hline $15-24$ & 123 & $10(8)$ & 1.0 & & 1.0 & \\
\hline $25-34$ & 119 & $10(8)$ & $1.00(0.32-3.08)$ & 0.99 & $1.15(0.65-2.04)$ & 0.64 \\
\hline$>34$ & 64 & $8(12)$ & $1.99(0.65-6.05)$ & 0.23 & $1.33(0.67-2.63)$ & 0.42 \\
\hline Practices regular vaginal douching & 279 & $22(8)$ & $0.25(0.07-0.88)$ & 0.03 & $2.47(0.83-7.33)$ & 0.10 \\
\hline Last menstruation $<15$ days ${ }^{\text {b }}$ & 146 & $8(6)$ & $0.37(0.15-0.92)$ & 0.03 & $0.94(0.57-1.54)$ & 0.80 \\
\hline Genital warts on exam & 18 & $4(22)$ & $3.01(0.70-12.87)$ & 0.14 & $0.71(0.25-2.06)$ & 0.53 \\
\hline Genital ulceration on exam & 12 & $4(33)$ & $5.22(1.21-22.57)$ & 0.03 & $0.61(0.17-2.19)$ & 0.45 \\
\hline HSV-2 seropositivity & 195 & $19(10)$ & $1.03(0.36-2.95)$ & 0.36 & $0.71(0.39-1.27)$ & 0.25 \\
\hline Bacterial vaginosis & 131 & $14(11)$ & $1.08(0.44-2.69)$ & 0.86 & $1.15(0.69-1.91)$ & 0.60 \\
\hline \multicolumn{7}{|l|}{ HIV status: } \\
\hline HIV seronegative & 183 & $13(7)$ & 1.0 & & 1.0 & \\
\hline HIV $-1+$, CD4 >200 cells $/ \mu \mathrm{L}$ & 93 & $9(10)$ & $1.06(0.39-2.88)$ & 0.90 & $2.13(1.22-3.70)$ & 0.007 \\
\hline
\end{tabular}


HIV-1 +, CD4 $\leq 200$ cells $/ \mu \mathrm{L}$

NOTE: determined by logistic regression. OR, odds ratio; CI, confidence interval;

${ }^{a}$ odds ratio adjusted for HIV status, genital ulceration, regular vaginal douching, and last menstrual period less than 15 days prior to visit; ${ }^{b}$ women with amenorrhea and menopause were excluded from this group 


\section{Discussion}

The prevalence of cervical HPV 6/11 was high in this population and increased with immunosuppression. Unlike overall cervical HPV types, which had a strong association with both HIV and CD4+ count in this setting,[4] the association with HPV 6/11 was weaker, likely due in part to the smaller numbers of subjects who were HPV 6/11 positive.

Our data suggest that HPV 6 is more prevalent in women with genital warts than HPV 11, which was already reported from an aetiological study in Australia.[2] However, any relationship might be obscured by the fact that HPV DNA was recovered from the cervix and not directly from genital lesions.

The presence of genital ulcers, mainly caused by HSV-2 in Burkina Faso,[6] was strongly associated with HPV 6/11 but not with other HPV types. This suggests that HPV 6/11 may either cause or be acquired or transmitted through breaches of the genital mucosal surface, possibly induced by HSV-2 reactivations, although any biological differences between types remains unclear at this point. Conversely, we did not detect any association between HPV 6/11 and the presence of BV, often implicated in the acquisition of STIs and which might allow for persistence of HPV.[7] Regular vaginal douching, linked to disturbances of the vaginal milieu and increased STI risk in other settings, [8] was found to be protective for HPV 6/11 in this study. This might be secondary to mechanical factors which decrease DNA detection, although the sensitivity of HPV DNA detection does not seem impaired after washing.[9] Another African study has suggested a protective effect of douching on genital warts.[10] The follicular phase of the menstrual cycle was protective for HPV 
6/11, which might be due to an oestrogenic effect on HPV persistence,[11] although the role of hormonal factors on STIs remains poorly characterized in African women.

In conclusion, HPV 6/11 prevalence was high in this high-risk population, with a predominance of HPV 6. HPV 6/11 were found more frequently in women with genital ulcers and in those with HIV-related immunosuppression. 


\section{Key Messages:}

1. The prevalence of low-risk-HPV types 6 and 11 was relatively high (9\%) in this cohort of 306 high-risk women in Burkina Faso.

2. HIV infection and immune suppression were predictive of the presence of cervical HPV 6 and 11 and other HPV types.

3. HPV types 6 and 11, but not other HPV types, were strongly associated with concurrent genital ulcer disease, suggesting a role either in clinical presentation or transmission of HPV 6/11.

Acknowledgements: We wish to thank the women and the organisations of persons living with HIV/AIDS ('Yérelon', 'Espoir et Vie', Centre 'Solidarité Action Sociale' and 'Espoir pour Demain') who participated in this study; and staff at Service d'Hygiène, Bobo-Dioulasso, Burkina Faso.

Competing interests: We have no conflicts of interest to declare.

Funding: This study was funded by France's Agence Nationale de Recherches sur le SIDA et les Hépatites (ANRS), grants ANRS-1291\& ANRS-1285. Additional financial support was provided through the UK's Department for International Development (DFID)-funded Knowledge Programme on HIV/AIDS \& STI, and the Research Programme Consortia (RPC) on Research and Capacity Building in Sexual \& Reproductive Health and HIV in Developing Countries of the London School of Hygiene \& Tropical Medicine. The views expressed herein are those of the authors and do not necessarily reflect the official policy or position of DFID. 
Roles: N Nagot, P Mayaud and P Van de Perre designed the study, which was carried out by I Konaté, A Ouédraogo, and supervised by N Nagot. HPV testing was performed by MN Didelot-Rousseau and M Segondy in Montpellier. Statistical analyses were performed by A Low and reviewed by T Clayton and P Mayaud. First manuscript was drafted by A Low and P Mayaud with inputs and reviews from all coauthors, who approved the final version.

\section{Statement:}

"The Corresponding Author has the right to grant on behalf of all authors and does grant on behalf of all authors, an exclusive licence (or non exclusive for government employees) on a worldwide basis to the BMJ Publishing Group Ltd to permit this article (if accepted) to be published in STI and any other BMJPGL products and sub-licences such use and exploit all subsidiary rights, as set out in our licence http://group.bmj.com/products/journals/instructionsfor-authors/licence-forms".

Word count: 768 


\section{References:}

1. Castellsague X, Sanjose Sd, Aguado T, et al. HPV and Cervical Cancer in the World: 2007 Report. Vaccine. 2007;25:C1-C230.

2. Garland SM, Steben M, Sings HL, et al. Natural history of genital warts: analysis of the placebo arm of 2 randomized phase III trials of a quadrivalent human papillomavirus (types 6, 11, 16, and 18) vaccine. J Infect Dis. 2009;199:805-14.

3. Nagot N, Ouedraogo A, Ouangre A, et al. Is sexually transmitted infection management among sex workers still able to mitigate the spread of HIV infection in West Africa? J Acquir Immune Defic Syndr. 2005;39:454-8.

4. Didelot-Rousseau MN, Nagot N, Costes-Martineau V, et al. Human papillomavirus genotype distribution and cervical squamous intraepithelial lesions among high-risk women with and without HIV-1 infection in Burkina Faso. Br J Cancer. 2006;95:355-62.

5. Didelot-Rousseau MN, Courgnaud V, Nagot N, et al. Comparison of INNOLiPA HPV Genotyping v2 with PCR product subcloning and sequencing for identification of genital human papillomavirus genotypes in African women. J Virol Methods. 2006; 135:181-5.

6. Mayaud P, Nagot N, Konate I, Ouedraogo A, et al. Effect of HIV-1 and antiretroviral therapy on herpes simplex virus type 2: a prospective study in African women. Sex Transm Infect. 2008;84:332-7.

7. Watts DH, Fazzari M, Minkoff H, Hillier SL, Sha B, Glesby M, et al. Effects of bacterial vaginosis and other genital infections on the natural history of human 
papillomavirus infection in HIV-1-infected and high-risk HIV-1-uninfected women. J Infect Dis. 2005;191:1129-39.

8. Martino JL, Vermund SH. Vaginal douching: evidence for risks or benefits to women's health. Epidemiol Rev. 2002;24:109-24.

9. Chen FC, Shaw SW, Cheng PJ, Hsueh S, Lin CT. Diagnosis of human papillomavirus infection by abnormal cervical cytology is highly reproducible after vaginal douching. Taiwan J Obstet Gynecol. 2008;47:412-6.

10. La Ruche G, Messou N, Ali-Napo L, Noba V, Faye-Kette H, Combe P, et al. Vaginal douching: association with lower genital tract infections in African pregnant women. Sex Transm Dis. 1999;26:191-6.

11. Sonnex C. Influence of ovarian hormones on urogenital infection. Sex Transm Infect. 1998;74:11-9. 